\title{
nature
} medicine

VOLUME 7 • NUMBER 6 • JUNE 2001

\section{Sex matters}

Two appointments of women biomedical scientists to senior positions last month should gladden the hearts of female re searchers who believe the career ladder to be fraught with broken rungs because of their gender. Cardiovascular researcher Ketty Schwartz was appointed as director of research in France's research ministry and molecular biologist Shirley Tilghman became the first president of Princeton University (page 646).

Sadly, Tilghman and Schwartz arestatistical outliers. Tilghman is only the third woman ever to be made president of an Ivy League University, and Schwartz is the first woman in her job.

Thisisn't to say that therearen't other examples of outstanding women bosses in biomedical research. Ruth Kirschstein is presently the acting director of the $\mathrm{NIH}, \mathrm{a}$ role that she has played before, and last month's Nature Medicine profile of Elizabeth Blackburn, the woman who discovered telomerase, shows how a positive female role model can drastically influence the gender distribution of scientists working in a given field (Nature Med. 7, 520; 2001).

But the score is far from even. From the 116 people that have been awarded the Nobel Prize for Physiology and Medicine since 1950, only 5 are women: Rosalyn Yalow, Barbara McClintock, Rita LeviMontalcini, Gertrude Elion and Christiane Nüsslein-Volhard. No woman has ever been awarded Japan's International Prize for Biology in its 16-year history. A quick assessment of the manuscripts published by Nature Medicine in the last 6 months shows

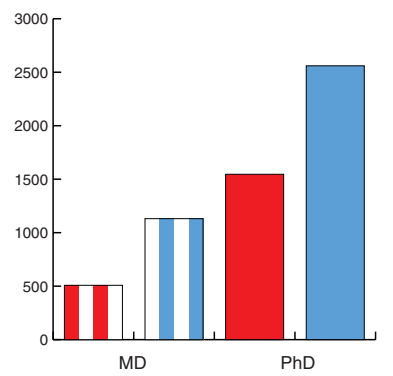

Number of MDs and PhDs at NIH as of 5 May 2001. ㅁ, Male; $\mathbf{\square}$, Female. that out of 59 senior authors, only 13 are women. And a breakdown of the sexes employed at the present time at the NIH shows highly disproportionate figures.

Data show that women leave science careers twice as frequently as men (Career Enginering, 4, 5; 1996). The reasons why they drop out are complex and range from conflicts with motherhood, to perceived and actual discrimination. For example, women's salaries in science lag behind men's by $12-15 \%$ (The Equity Agenda: Women in Science, Mathematics and Engineering. Ann Arbor, MI: Center for the Education of Women, 1995).

But on this occasion it's not our aim to dis cuss strategies that might best stem the exodus of femalesfrom science, except to say that the simplest methods are often the best. Promoting qualified women to decision-making positions will surely help to even-up pay scales, level career opportunities and pavethe way for more women to take on high-profile jobs in research if they meet the standard. Women scientists can make it to the top and acknowledging this will help the cause.

\section{Quick success for cancer kinase treatment}

Last month the US Food and Drug Administration (FDA) approved STI571 for the treatment of chronic myeloid leukemia (CML). Although Phaselll clinical trials are not complete, meaning that the long-term efficacy and safety profile of the drug is not yet determined, the preliminary results from Phase I and II trials were so encouraging that the manufacturer, Novartis, applied for a fast-track review last February. The FDA should be applauded for its alacrity, enabling a highly promising cancer drug to become available much sooner to patients.

$\mathrm{CML}$ is a rare form of leukemia affecting 4,500 people in the US each year. It is a clonal hematopoietic stem-cell disorder characterized by the Philadel phia chromo- some, the result of a bal anced translocation between chromosomes 9 and 22. This translocation leads to a gene fusion the product of which, BCR-ABL, is constitutively 'on' and activates a number of signal transduction pathways involved in cell proliferation and apoptosis, leading to myeloid proliferation.

CML is a particularly good disease target since it is one of the few malignancies that can beascribed to an underlying defect in a single molecule. STI571 specifically inhibits ABL1 protein tyrosine kinase, and these results elegantly illustrate the power of research founded on a good understanding of the underlying mechanisms of biological action. In addition, STI571 blocks autophosphorylation of the Kit and PDGF receptors, and the drug is now in clinical trials for cancers in which these kinases are activated, such as gastrointestinal stromal tumors, some gliomas and tissue sarcomas.

Of course, it's not all good news. Although STI571 therapy has yielded impressive results for patients in the chronic phase of $C M L$, the drug is not effective in the acute phase and long-term treatment has led to the development of drug-resistant tumors. Combination therapies are now being developed that may circumvent these problems.

Nevertheless, STI571 is one of over 16 new kinase inhibitors that are now in development and its success offers real hope that molecular targeted therapy is finally becoming a reality. 